\title{
Öntisztuló felületek alkalmazása szerves anyagok eliminálására, ill. biológiai rendszerek ártalmatlanítására
}

\author{
JANOVÁK László*, DEÁK Ágota, MÉRAI László, TALLÓSY Szabolcs Péter és DÉKÁNY Imre \\ Szegedi Tudományegyetem, Interdiszciplináris Kiválósági Központ, Fizikai Kémiai és Anyagtudományi Tanszék, \\ Rerrich Béla t. 1., 6720, Szeged, Magyarország
}

\section{Bevezetés}

A különböző humán patogén mikroorganizmusok és azok közül is a nozokomiális fertőzéseket okozó baktériumok évtizedek óta jelentős és egyre fokozódó közegészségügyi, terápiás és gazdasági problémát jelentenek. Ezek a mikroorganizmusok egyes esetekben súlyos morbiditással és mortalitással járó betegségeket okoznak, és amennyiben megfelelő kezelés hiányában rezisztencia alakul ki az antibiotikumok és kezelési módszerek ellen a kórházi bennfekvési idő növekszik az antibiotikum felhasználás és ellátás költségével együtt, nem beszélve a limitált kórházi ágyakról ${ }^{1}$. A kórházi környezet kedvez a multirezisztens baktériumok kialakulásának, szelektálódásának, terjedésük állandó forrása és rezervoárja ${ }^{2}$. A multirezisztens kórokozók által kiváltott fertőzések jelentősége igen nagy, tekintettel a súlyosabb kórformákra, a szükülő terápiás lehetőségekre, a rosszabb gyógyulási esélyekre és a rendkívül költséges terápiás eljárásokra ${ }^{3}$. Az Európai Betegségmegelőzési és Járványügyi Központ szakembereinek becslései szerint az Európai Unió 27 tagállama és 498 millió lakosa körében évente hozzávetöleg 4,5 millió nozokomialis fertőzés fordult elő, melyek éves halálozása 37000 körüli és további százezres nagyságrendü haláleset függ össze olyan betegségekkel, amelyet a páciensek egészségügyi intézményekben kaptak $\mathrm{el}^{4}$. Ezek a számok, illetve a kezelésekhez tartozó gazdasági terhelés indokolja egy jól kialakított és megfontolt prevenciós program kialakítását, amelybe beletartozik a betegszobák, mütők és várók megfelelő fertőtlenítése is ${ }^{5}$. Erre számos módszer alakult ki az utóbbi évtizedekben, ezek között szerepelnek a különböző vegyszerekkel illetve germicid lámpákkal történő eljárások ${ }^{6}$. A tisztítószerek alkalmazási területe a padlótól és falaktól a felületeken át az eszközökig és müszerekig terjed, a fertőtlenítő hatás mellett a tisztító képesség és a környezetvédelmi szempontok is fontos szerepet játszanak. A fertőtlenítő eljárások történhetnek fizikai úton, kémiai úton vagy ezek kombinálásával. Fizikai fertőtlenítés történhet fózéssel, gőzöléssel, vagy az UV tartományban emittáló fényforrás segítségével. Kémiai fertőtlenítés körébe tartoznak a vegyszerrel történő fertőtlenítési módszerek, illetve fertőtleníthetünk még gázzal és különböző aeroszolokkal is. A felületek fertőtlenítése fertőzés szempontjából frekventált területen leggyakrabban vegyszerekkel és UV-fénnyel történik, ezek előnyei a gyors antimikrobás hatás, viszont a leárnyékolt területeken a mikroorganizmusok tovább képesek szaporodni ${ }^{7}$. Ma már tudjuk, hogy a vegyszerekkel történő fertőtlenítés káros a környezetre és az emberre egyaránt, az UV-fény pedig szövetkárosító hatású, így ártalmas az emberi szervezetre is ${ }^{8}$.

\section{Fotokatalitikus elven müködő kompozit alapú bevonatok alkalmazása felületek tisztítására}

Az előző fejezetben felsorolt eljárások mellett ma már új technológiákat is használnak annak érdekében, hogy a fertőtlenítés folyamata sokkal hatékonyabb legyen azon felül, hogy az emberi szervezetre nincs káros hatással ${ }^{9}$. Az egyik ilyen innovatív és egyre inkább elterjedő megoldás a (foto)reaktív nanorészecskékkel történő felületi mikrobiális csíraszám csökkentés. A nanorészecskékkel történő fertőtlenítés lényege, hogy az antimikrobás hatású részecskék a méretüknél fogva kapcsolatba kerülnek a mikroorganizmusokkal, vagy behatolnak a mikroorganizmusok sejtfalán, sejtmembránján keresztül és ott kifejtve hatásukat elpusztítják a baktériumok, vírusok és gombák széles spektrumát ${ }^{10}$. Régóta ismert az is, hogy a félvezető alapú fotokatalizátor anyagok (pl. $\mathrm{TiO}_{2}$, vagy $\mathrm{ZnO}$ ) jelenlétében megfelelő hullámhosszúságú fény bevilágítás mellett erőteljesen oxidáló reagensek, pl. hidroxilgyök $(\mathrm{OH})$ és szuper-oxidion $\left(\mathrm{O}_{2}^{-}\right)$, valamint hidrogén peroxid $\left(\mathrm{H}_{2} \mathrm{O}_{2}\right)$ képződik ${ }^{11}$. Ezek a reaktív speciesek megfelelően nagy oxidációs potenciállal bírnak ahhoz ${ }^{12}$, hogy a fotokatalizátor részecskék felületén adszorbeálódott szerves anyagokat fotooxidálják ${ }^{13}$. A fotokatalizátor részecskék e tulajdonságát kihasználhatjuk arra is, hogy a képződött reaktív gyökök segítségével a felületen adszorbeálódott mikroorganizmusokat elimináljuk, azaz a mikrobiális aktivitást csökkentsük. A folyamat minősítésére ma már számos mérési módszer és szabványosított eljárás áll rendelkezésre ${ }^{14,15}$.

A fotokatalizátor részecskék gyakorlati alkalmazásának szempontjából fontos a felületen rögzíteni a katalizátorrészecskéket, hogy ezáltal azok alkalmazását minél inkább elősegítsük (1. ábra). Erre alkalmasak lehetnek különböző szerves, vagy szervetlen rögzítő anyagok ${ }^{16}$. A legjobb mechanikai tulajdonságokkal rendelkező kompozit filmeket polimer kötőanyagok alkalmazása mellett sikerült elöállítanunk és fotokatalitikus mérésekkel igazoltuk, hogy polimerrel immobilizált fotokatalizátor részecskéknek kb. 50\%-al csökken ugyan a fotokatalitikus hatásfoka, a tiszta fotokatalizátor filmhez képest, de a kompozit réteg még így is jelentős fotokatalitikus aktivitással bír (2. ábra) ${ }^{17}$. 


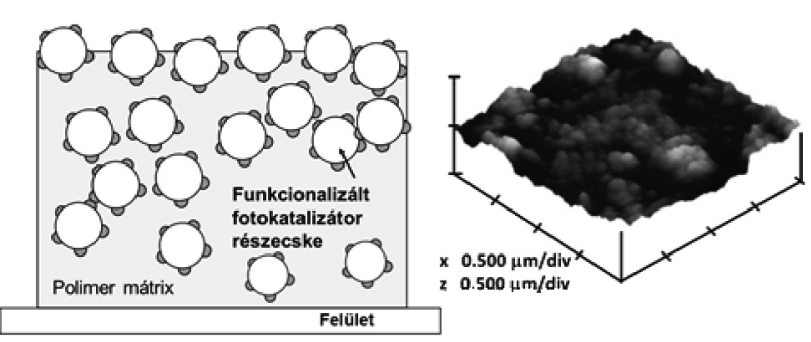

1. Ábra. A polimer kötőanyaggal immobilizált fotokatalizátor részecskék által képzett kompozit vékonyréteg sematikus ábrája, ill. a film felületének atomerő mikroszkópos felvétele.

2017-es dolgozatunkban bemutattuk, hogy ha a $\mathrm{TiO}_{2}$ nanorészecskéket hidroxiapatit (HAp) lamellákon rögzítjük, akkor a szervetlen HAp lamellák ,távtartóként” funkcionálva megakadályozzák a direkt kontaktust a $\mathrm{TiO}_{2}$ fotokatalizátor részecskék és a polimer mátrix között és ezáltal a HAp tartalmú kompozit réteg fotodegradációja 75\%-al csökkenthető volt a lamellákat nem tartalmazó $\mathrm{TiO}_{2} /$ polimer kompozithoz képest (3. ábra) ${ }^{18}$. Sőt, szerkezetvizsgálati módszerekkel azt is igazoltuk, hogy a HAp mikrolamellák felületén a $\mathrm{TiO}_{2}$ nanorészecskék egyenletesen oszlanak el, nem képeznek aggregátumokat, ezáltal nő a fotokatalizátor hozzáférhetősége, mely nagyobb fotokatalitikus és antibakteriális hatásfokot eredményezett a HAp-ot nem tartalmazó kompozit réteghez képest ${ }^{18}$.

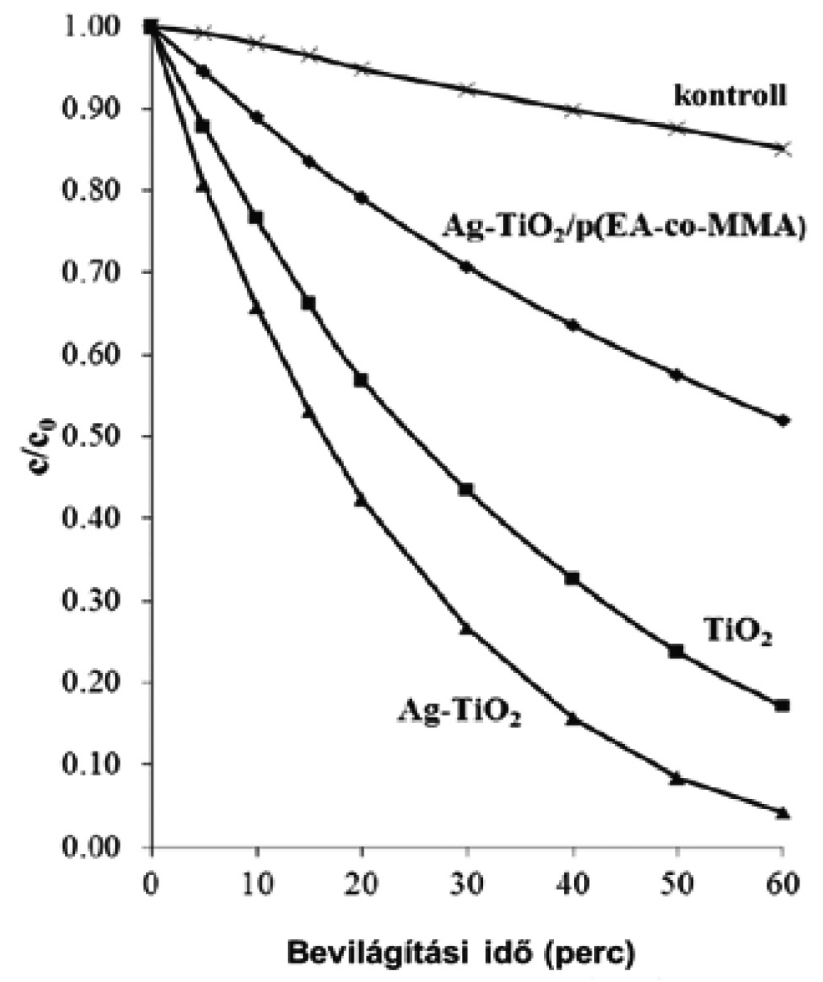

2. Ábra. Etanol tesztmolekula $\left(\mathrm{c}_{0}=0.36 \mathrm{mM}\right)$ relatív koncentrációjának csökkenése a $\mathrm{P} 25 \mathrm{TiO}_{2}$ ill., plazmonikus Ag- $\mathrm{TiO}_{2}$ fotokatalizátor rétegen, valamint az Ag- $\mathrm{TiO}_{2} /$ poli(etil- akrilát- ko- metil- metakrilát) alapú kompozit rétegen ( $60 \%$ fotokatalizátor tartalom) A mérések $405 \mathrm{~nm}$-en emittáló (kék) LED fényforrás alkalmazás mellett történtek.

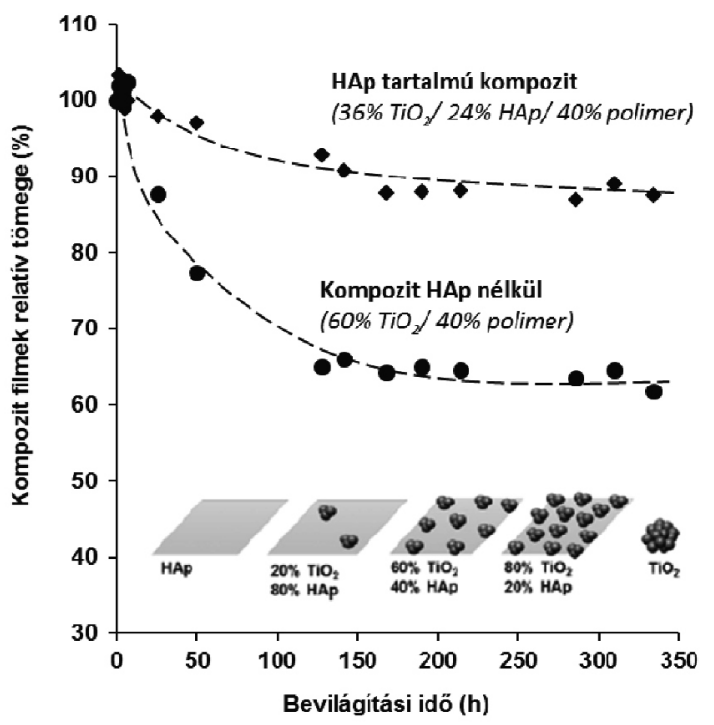

3. ábra. A hidroxiapatit (HAp) tartalom hatása a $\mathrm{TiO}_{2}$ fotokatalizátor részecskéket tartalmazó polimer alapú kompozit rétegek gravimetriásan meghatározott tömegére a bevilágítási idő függvényében. A HAp lamellák jelenlétében a polimer nemkívánatos fotodegradációja jelentősen lecsökkent.

A polimer kötőanyag alkalmazása mellett kialakított fotoreaktív rétegek antimikrobiális tulajdonságát különbözö szabványosított módszerek alkalmazásával igazoltuk dolgozatainkban ${ }^{17-20}$. A fotokatalizátorok baktériumokra gyakorolt destruktív hatását a bakteriális sejtfalat alkotó és a sejtfal stabilitásáért jelentős mértékben felelős peptidoglikán (murein) réteg esetében is bemutattuk (4. ábra) ${ }^{20}$.

\section{Fotokatalizátor jelenlétében}

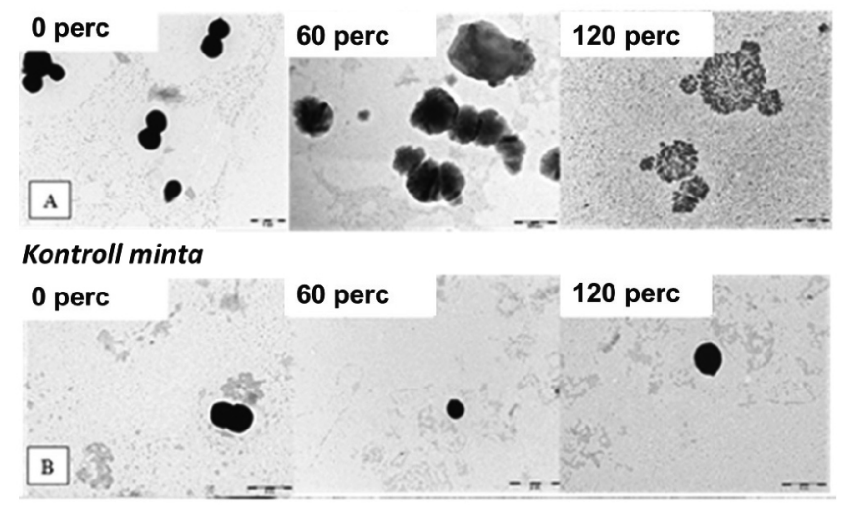

4. Ábra. Staphylococcus aureus baktériumok izolált peptidoglikán rétegének szerkezetváltozása LED fényforrással történő bevilágítás ( $\lambda_{\max }=405 \mathrm{~nm}$ ) hatására fotokatalizátor jelenlétében (felső sor), ill. fotokatalizátor nélkül (alsó sor)

A mérések során a bakteriális sejtfalkomponens szerkezetét és $\mathrm{Ag}-\mathrm{TiO}_{2}$ plazmonikus fotokatalizátor hatására bekövetkező degradációját transzmissziós elektronmikroszkópos felvételekkel (TEM) igazoltuk: a Grampozitív Staphylococcus aureus baktériumok peptidoglikán rétege már a bevilágítás 60 . percében degradáció jeleit mutatta, majd a 120 perces bevilágítása követően a vizsgált szuszpenzióban a Staphylococcus aureus sacculusok esetében teljes degradáció, a sacculusok dezintegrálódása figyelhetö meg. 
A bakteriális sejtfal degradációja révén ezek a fotokatalizátor részecskék tehát alkalmasak arra, hogy a kiindulási felületeinket antibakteriális tulajdonságokkal ruházzuk fel. Ennek igazolására olyan telítetlen poliészter gyanta felületeket dolgoztunk ki, melyek mindössze 2\%-os antibakteriális adalékanyag tartalommal rendelkeztek és szabványosított $^{21}$ módszerrel vizsgáltuk a felület antimikrobiális hatásfokát. A mikrobiológiai vizsgálatok alapján az állattenyésztésben jelenlévő és meglehetősen ellenálló Enterococcus faecalis baktériumok 100\%- a elpusztult az antibakteriális tulajdonságokat mutató kompozit tesztfelületen (5. ábra), de az olyan baktériumok is, mint pl. az Escherichia coli, ill. a Staphylococcus aureus, melyek súlyos fertőzéseket vagy mérgezéseket okozhatnak, szintén 100\%-os inaktiválódást mutattak a kompozit rétegeken (GINOP-2.1.7-15-2016-00142).
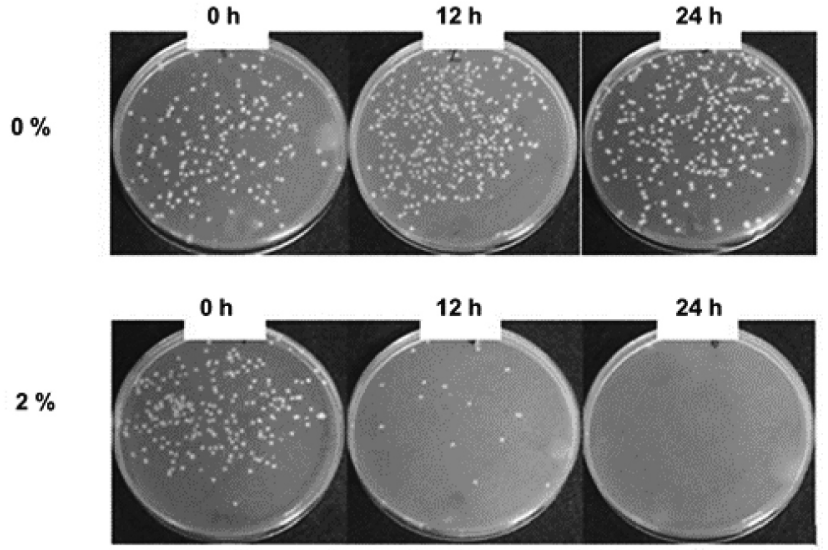

5. Ábra. Enterococcus faecalis baktériumok telepeinek fotói a kontroll (felső sor), ill. a 2\%-nyi antibakteriális adalékanyag tartalmú poliészter alapú kompozitok (alsó sor) felületéről. Jól látszik, hogy az antibakteriális adalékanyag tartalmú kompozit felületén inaktiválódtak/ elpusztultak a baktériumok (alsó sor) a bevilágítás során.

\section{Bio-inspirált lótusz-szerű szuperhidrofób bevonatok}

A természet által kidolgozott technológiai megoldásokat az anyagtudományi kutatásokkal foglalkozó szakemberek mindinkább igyekeznek kihasználni úgy, hogy az így kidolgozott ún. bio- mimetikus, vagy bio- inspirált megoldások a legkülönbözőbb területeken alkalmazhatóak legyenek. Jól ismert például, hogy az öntisztuló tulajdonságokkal rendelkező lótuszvirág levelét és virágát a víz nem nedvesíti, olyan csepp képződik rajtuk, amely nem tapad meg a növények felületén, hanem lepereg arról, sőt közben a növényen található szennyeződéseket is eltávolítja. Ennek mintájára a mesterségesen kialakított lótusz- szerü felületek is vízlepergető, öntisztuló tulajdonságokkal bírnak, ami azt jelenti, hogy a desztillált víz kontaktszöge $(\Theta)$ a felületen meghaladja a $150^{\circ}$ - os értéket (6. ábra). W. Barthlott és N. Ehler német botanikusok az 1970-es években végzett kutatásai alapján ${ }^{22}$, a növényi részeken lévő mikroszkopikus méretü felületi képletek szabályos mintázata teszi a leveleket nagymértékben vízlepergetővé, azaz szuperhidrofób tulajdonságúvá. A szakemberek azt is bemutatták, hogy a növény leveleinek finomszerkezete mind mikro-, mind nanoszinten érdességet mutat, ui. a 10-15 $\mu \mathrm{m}$-es felületi kiemelkedéseken nanoméretü gyanta kristályok találhatóak. Így a témával foglalkozó szakemberek a legkülönbözőbb müszaki megoldásokkal igyekeznek leutánozni a lótuszlevél finom mikro-, ill. nanométeres skálán is tapasztalható fraktálszerü struktúráját ${ }^{23}$

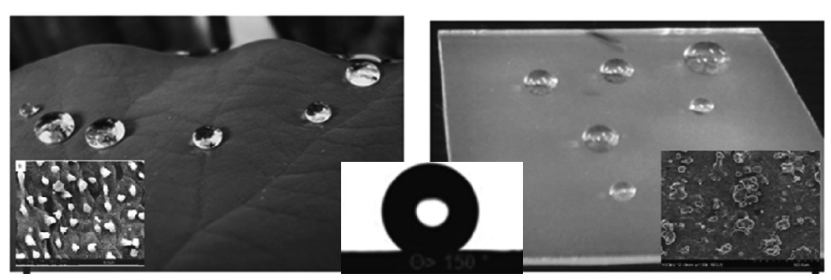

6. Ábra. A természetes lótuszlevél (Nelumbo nucifera), ill. a mesterséges bevonat fotója a felületi vízcseppekkel $\left(\Theta>150^{\circ}\right)$, ill. a rétegek hasonló finomszerkezetét, azaz érdességét bemutató pásztázó elektron-mikroszkópos felvételek.

$\mathrm{Az}$ extrém nedvesedési tulajdonságokat mutató szuperhidrofób felületek kialakításához tehát egy megfelelően kis felületi energiával rendelkező hidrofób sík felületnek kell növelni a felületi érdességét. Erre számos szintézismódszer alkalmas: a bonyolultabb nagymüszeres ${ }^{24}$, vagy templát alapú technikák ${ }^{25}$ mellett akár egyszerü porlasztásos úton ${ }^{26}$ is ki tudunk alakítani szuperhidrofób felületeket tetszőleges méretben. Ez utóbbi esetben pl. úgy is eljárhatunk, hogy a hidrofób polimer felületi érdességét kis energiájú hidrofób szervetlen töltőanyagok alkalmazásával növeljük. A 7. ábrán azt láthatjuk, hogy a profilometriás mérések alapján a töltőanyag mentes, sík felületü perfluorodecil-akrilát fluoropolimer réteg felületi érdessége $\mathrm{R}_{\mathrm{q}}=1,2 \pm 0,4 \mu \mathrm{m}$ volt és a hidrofób sík felület által megszabott peremszög $\Theta=98,7^{\circ}$-nak adódott, mely jellemzö érték a teflon- szerü bevonatokra ${ }^{26}$. Azt is láthatjuk, hogy ha hidrofóbizált szilika töltőanyagot oszlattunk el a fluoropolimer rétegben, akkor annak felületi érdesség $\mathrm{R}_{\mathrm{q}}=$ $11,7 \pm 2,2 \mu \mathrm{m}$ - re nőtt és ezzel párhuzamosan a kompozit filmre meghatározott kontaktszög $\Theta=154,3^{\circ}$-nak adódott, azaz elértük a szuperhidrofób tartományt. A különböző nagyítású pásztázó- elektronmikroszkópos (SEM) felvételeken jól látható az előállított kompozit film mikro- és nano- szinten vett érdessége, ui. a rétegszintézis során a nanoméretü $(\mathrm{d}=\mathrm{kb} .50 \mathrm{~nm})$ szilika részecskék 5-40 $\mu \mathrm{m}$ átmérőjü, azaz mikroméretű gömböket képeztek. Azaz hasonlóan a természetes lótuszlevélhez- a mesterséges lótusz- szerü felület kétfajta skálán vett érdessége is biztosított a porlasztásos filmképzés során.

Azt is érdemes még megjegyezni, hogy a természetes lótuszlevél csak szuperhidrofób tulajdonságokkal rendelkezik, azaz a nagy felületi feszültséggel $\left(\gamma_{\mathrm{v}}=\sim 72\right.$ $\mathrm{mN} / \mathrm{m} 25^{\circ} \mathrm{C}$-on) rendelkező víz mellett a többi, kisebb felületi feszültséggel $(\gamma<30 \mathrm{mN} / \mathrm{m})$ bíró apoláros folyadék jól nedvesíti a felületét. Ezzel szemben a mesterséges bevonatok esetében szuperoleofób tulajdonságok is elérhetők, azaz a réteget a kis felületi feszültségü apoláros folyadékok sem fogják nedvesíteni. 


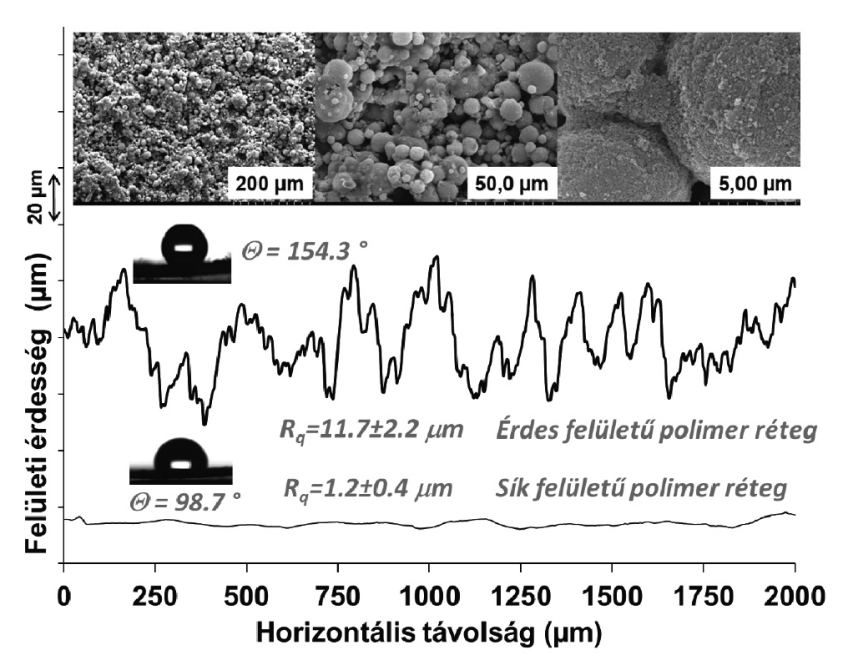

7. Ábra. A kiindulási sík felületű perfluorodecil-akrilát fluoorpolimer réteg, ill. az érdesített fluoropolimer kompozit réteg profilometriás görbéi a rétegekre meghatározott érdesség- és peremszög értékekkel. A különböző nagyítású pásztázó- elektronmikroszkópos (SEM) felvételeken jól látható a kompozit film mikro- és nano- szinten vett érdessége is.

Ennek reprezentálására a 8. ábrán láthatjuk, hogy a kiindulási hidrofil, nagy felületi energiával rendelkező rozsdamentes acél felület nedvesedési tulajdonságai alapvetően megváltoztak a szuperoleofób bevonat kialakítása után: a kezeletlen felületen a nyersolaj szétterült, jól nedvesítette azt, még a bevonattal ellátott acél felületen a hidrofób folyadék minimális nedvesedés mellett legördült a felületről.

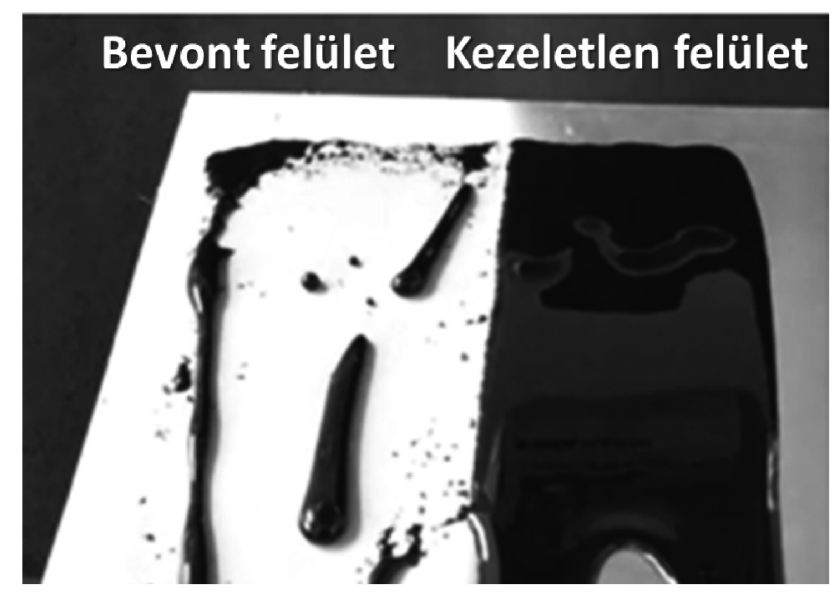

8. ábra. A szuperhidrofób és -oleofób bevonattal ellátott és a kiindulási rozsdamentes acélfelületek nedvesedési tulajdonságai apoláros nyersolaj tesztfolyadék esetében

\section{Kettős, szuperhidrofób és fotoreaktív tulajdonságokkal rendelkező vékonyrétegek}

Az elöző fejezetben bemutatottak alapján szuperhidrofób, vízlepergetô felületek kialakításához egy kis felületi energiával rendelkező ún. teflon- szerü felületet kell megfelelő felületi érdességgel ellátni. Jelen fejezetben láthatjuk, hogy megfelelő szintézismódszerek és töltőanyagok megválasztásával kialakíthatóak olyan többfunkciós felületek, melyek egyszerre mutatnak szuperhidrofób és fotoreaktív tulajdonságokat. Ezzel a bevonatok előnyös tulajdonságai kombinálhatóak, ill. kiterjeszthetjük azok felhasználási körét. A kettős, szuperhidrofób és fotoreaktív tulajdonságokat mutató felületek kialakításának elvi lehetőségét az adta, hogy 2015ben munkacsoportunk sikeresen szintetizált egy olyan réteges- kettős hidroxid (LDH) alapú fotokatalizátor részecskét, mely speciális morfológiával rendelkezett: az LDH lamellák speciális, sugárirányú elrendeződésének köszönhetően a kialakult mikronos részecskék felülete strukturált, érdes jelleget mutatott (9. ábra) ${ }^{27} \cdot \mathrm{Az} \mathrm{LDH}$ részecskék kihevítése után -köszönhetően a kiindulási LDH cink tartalmának- cink- oxid fázis is keletkezett, mely egy jól ismert félvezető fotokatalizátor, a részecskék gerjesztési küszöbenergiája 3,23 eV-nak adódott. A fotokatalizátor részecskék preparálását követően azokból vékonyrétegeket szintetizáltunk. Jól ismert azonban, hogy a „hagyományos” félvezető- oxid alapú fotokatalizátor részecskék bevilágítás hatására ún. szuperhidrofil tulajdonságokat mutatnak, azaz a víz nagyon jól nedvesíti a felületüket, a mért kontaktszög közel nulla. Ezért a kiindulási hidrofil fotokatalizátor részecskék által képzett vékonyréteg felületi energiáját csökkenteni kellett.

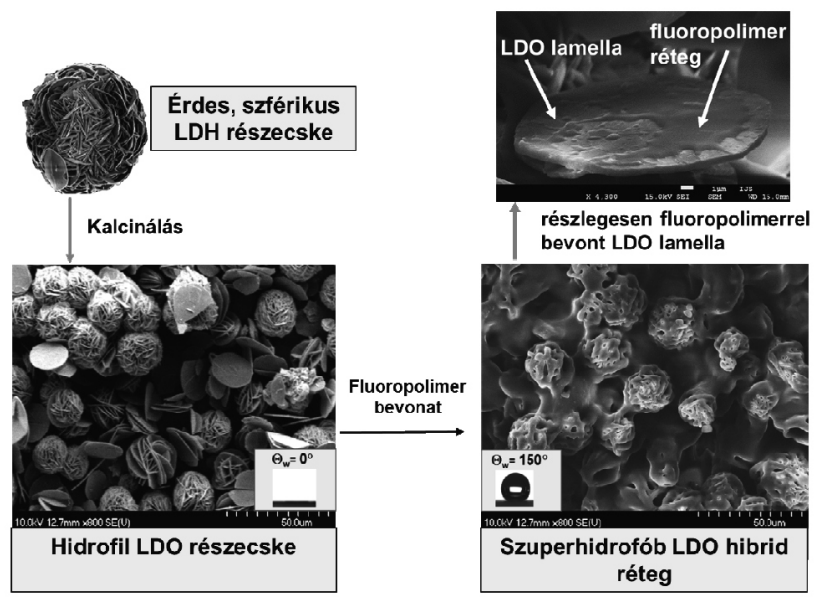

9. ábra. Az érdes felülettel rendelkező réteges- kettős oxid (LDO) mikrorészecskék által képzett film felületi energiájának csökkentése perfluorodecil-akrilát fluoropolimer alkalmazásával.

A kalcinálás után kapott, érdes felülettel rendelkező rétegeskettős oxid (LDO) fotokatalizátor részecskék felületi energiáját jelen esetben is fluoropolimer alkalmazásával csökkentettük, mely egyben a fotokatalizátor részecskék felületi immobilizációját is biztosította ${ }^{26}$. A 9. ábrán láthatjuk, hogy a fluoropolimer részlegesen beborította a hidrofil részecskék felületét, így végeredményben az érdes felület felületi energiájának csökkentése után a kialakított kompozit film szuperhidrofób tulajdonságokat mutatott, a szabad fotokatalizátor felszín pedig a kompozit réteg fotokatalitikus tulajdonságait biztosította.

A réteg fotokatalitikus hatásfokát szilárd/ folyadék határfelületen igazoltuk is. A mérések kivitelezése során benzoesav tesztmolekula fotodegradációját spektrofotometriás mérésekkel követtük nyomon, UV-A fényforrás $(\lambda \max =365$ $\mathrm{nm}$ ) alkalmazása mellett (10. ábra). Négy óra bevilágítási idő elteltével, a kiindulási polimer réteg nem mutatott fotokatalitikus aktivitást szemben az LDO fotokatalizátor 
tartalmú kompozit rétegekkel. A 240 perces fotokatalitikus mérések során, a kiindulási $0,17 \mathrm{~g} / \mathrm{L}$-es benzoesav vizes oldat koncentrációja 24\%-kal csökkent a 80\% LDO tartalmú kompozit film $\left(\mathrm{A}=25 \mathrm{~cm}^{2}\right)$ esetében. Továbbá azt is láthatjuk, hogy a fotokatalizátor arányának növelésével a mért peremszög értékek szintén nőttek, mely a növekvő felületi érdességnek volt köszönhető. $80 \%$ fotokatalizátor tartalomnál a kompozit réteg már megfelelő érdességgel rendelkezett a szuperhidrofób hatás $\left(\Theta=148^{\circ}\right)$ kialakulásához, így ennél az összetételnél kettős fotoreaktív és vízlepergető tulajdonságokat mutatott a vékonyréteg.

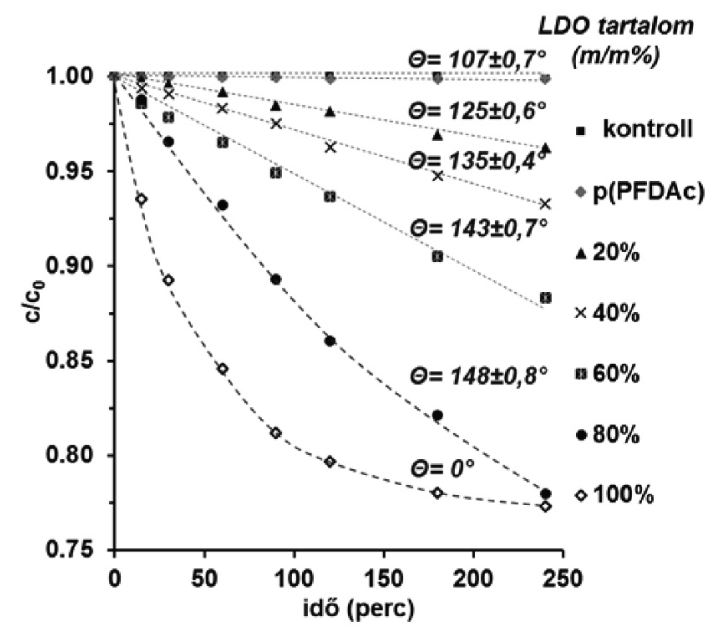

10. ábra. Vizes közegü benzoesav oldat $(0.17 \mathrm{~g} / \mathrm{L})$ relatív koncentrációjának csökkenése a bevilágítási idő (UV-A fényforrás; $\lambda_{\max }=365 \mathrm{~nm}$ ) függvényében az egyre növekvő LDO fotokatalizátor tartalommal rendelkező $25 \mathrm{~cm}^{2}$ - es kompozit filmeken.

A bemutatott bifunkcionális bevonat, ill. bevonatképző anyag alkalmazásával ötvözni lehet a kis energiájú folyadéklepergető felületek, ill. az öntisztuló és antibakteriális tulajdonságokkal rendelkező fotokatalitikus vékonyrétegek kedvező tulajdonságait. Azaz a vékonyrétegek egyszerre mutatnak szuperhidrofób és fotokatalitikus tulajdonságokat.

Ezek a kettős szuperhidrofób és fotokatalitikus tulajdonságokkal rendelkező hibrid vékonyrétegek az antimikrobiális felületek kialakítása terén is alkalmazhatóak. Jól ismert az irodalomban, hogy a felületen adszorbeálódott baktériumok többsége előnyben részesíti a nagy energiájú hidrofil felületeket. Mikrobiológiai méréseink alapján a vizsgált Staphylococcus aureus, Pseudomonas aeruginosa és Escherichia coli tesztbaktériumok bevilágítás hatására fotodegradációt szenvedtek a kompozit filmek fotokatalizátor részecskéinek felületén. $\mathrm{A}$ fentiekben láthattuk, hogy a kompozit rétegek heterogén felülettel rendelkeznek: a hidrofil fotokatalizátor részecskék felülete részben hidrofób fluoropolimerrel fedett. Mikrobiológiai tesztjeink alapján a Pseudomonas aeruginosa tesztbaktériumok a heterogén felszín hidrofil fotokatalizátor részecskéin adszorbeálódtak elsősorban, a hidrofób polimer részekkel szemben. Egy speciális baktérium festési eljárással, ill. fluoreszcens mikroszkóp alkalmazásával különbséget tudunk tenni az élő és az inaktiválódott, elpusztult baktériumok között is, ui. a módszerből kifolyólag az elő baktériumok zöld színnel, még az inaktiválódott baktériumok piros színnel jelennek meg a mikroszkópos felvételen ${ }^{20}$. A 11 . ábrán azt is láthatjuk, hogy 120 perces bevilágítás hatására a fotokatalizátor részecskék felületén adszorbeálódott Escherichia coli tesztbaktériumok elpusztultak, azaz a bevonat antibakteriális tulajdonságokkal rendelkezik.
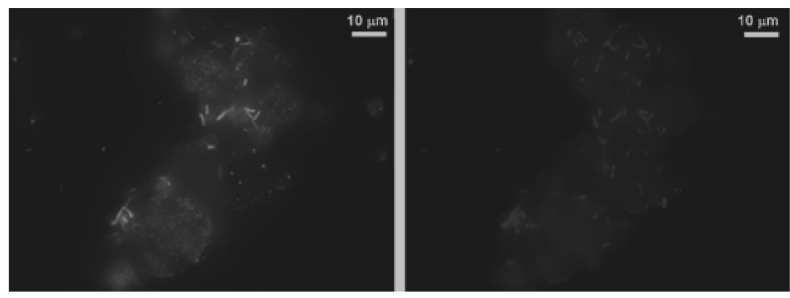

11. ábra A hibrid rétegek fotokatalizátor részecskéin adszorbeálódott Escherichia coli ATCC 29522 baktériumok fluoreszcens- mikroszkópos felvételei bevilágítás előtt, ill. 120 perces bevilágítást követően.

$\mathrm{Az}$ eddigiekben olyan vékonyrétegeket láthattunk, melyek legalább két komponensűek: a szervetlen fotokatalizátor részecskék biztosítják a megfelelő felületi érdességet, ill. a fotokatalitikus tulajdonságokat, míg a hidrofób polimer felelős a kis felületi energiáért. Legújabb eredményeink alapján azonban elektromosan vezető polimerek alkalmazásával egykomponensű, monolitikus polimer filmek is kialakíthatóak a fenti tulajdonságok megőrzése mellett ${ }^{28}$. Erre az adott lehetőséget, hogy a legújabb kutatások alapján ezek a polimerek fotokatalitikus tulajdonságokkal is rendelkeznek ${ }^{29,30}$. 2018-as dolgozatunkban bemutattuk, hogy a poli(3-hexiltiofén) /P3HT/ vezető polimer oldat szolvatáltsági viszonyainak változtatásával a polimer oldatból, ill. diszperzióból készített polimer filmek érdessége szisztematikusan változtatható volt, mely hatással volt a filmek nedvesedési tulajdonságaira ${ }^{28}$. A 12A. ábrán láthatjuk, hogy a sík P3HT filmre -Zismann módszere ${ }^{31}$ alapjánmeghatározott $19,8 \mathrm{~mJ} / \mathrm{m}^{2}$-es felületi energia érték a polimer érdesítésével 16,4 $\mathrm{mJ} / \mathrm{m}^{2}$-re volt csökkenthető, melyhez $\Theta=151.2^{\circ}$-os peremszög, azaz szuperhidrofób nedvesedési tulajdonság tartozott. Az érdes és sík P3HT film szimulált napfény (LCS-100 solar simulator) bevilágítás hatására történő fotokatalitikus aktivitást pedig szilárd/ gáz határfelületen igazoltuk etanol tesztmolekula alkalmazása mellett (12B. ábra). 

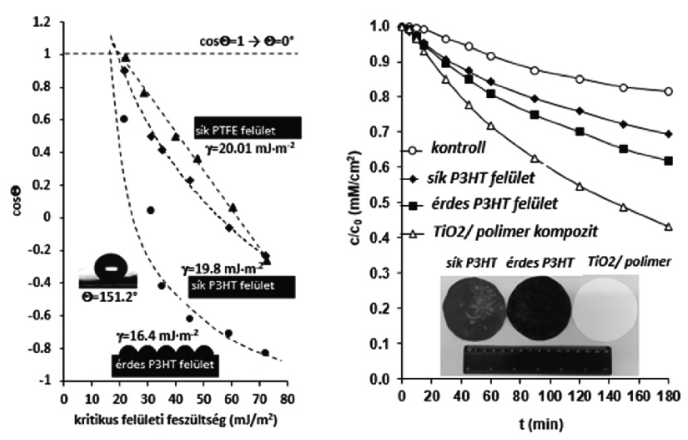

12. Ábra. Érdes és sík felülettel rendelkező poli(3-hexiltiofén) vezető polimer réteg felületi energiájának meghatározása Zismann módszerével, ill. etanol tesztmolekula $\left(\mathrm{c}_{0}=0.36 \mathrm{mM}\right)$ koncentrációjának relatív csökkenése a bevilágítási idő függvényében a fotoreaktív rétegeken.

\section{Hivatkozások}

1. Payne, D. J.; Gwynn, M. N.; Holmes, D. J.; Pompliano, D. L. Nat. Rev. Drug Discov. 2007, 6, 29-40., https://doi.org/10.1038/nrd2201

2. Banerjee, S. N.; Emori, T. G.; Culver, D. H.; Gaynes, R. P.; Jarvis, W. R.; Horan, T. J.; Edwards, R.; Tolson, J.; Henderson, T.; Martone, W. J., Am. J. Med. 1991, 91, 86-89., https://doi.org/10.1016/0002-9343(91)90349-3

3. Muto, C. A.; Jernigan, J. A.; Ostrowsky, B. E.; Richet, H. M.; Jarvis, W. R.; Boyce, J. M.; Farr, B. M. Infect. Control Hosp. Epidemiol. 2003, 24, 362-386., https://www.jstor.org/stable/10.1086/502213

4. Zarb, P.; Coignard, B.; Griskeviciene, J., Muller, A. Euro Surveill. 2012, 17 (46), 203-16., https://doi.org/10.2807/ese.17.46.20316-en

5. Barna, Z.; Kádár, M. Ann. Ist. Super. Sanita 2012, 48, 374-386., https://doi.org/10.4415/ANN 12_04_05

6. Buonanno, M.; Randers-Pehrson, G. A.; Bigelow, W.; Trivedi, S.; Lowy, F. D.; Spotnitz, H. M.; Hammer, S. M., Brenner, D. J. PLoS One 2013, 8, 76968. https://doi.org/10.1371/journal.pone.0138418

7. Arrage, A. A.; Phelps, T. J.; Benoit, R. E.; White, D. C. Appl. Envir. Microbiol. 1993, 59, 3545-3550.

8. Basak, S. C.; Bertelsen, S.; Grunwald, G. D. Toxicol. Lett. 1995, 79, 239-250.

https://doi.org/10.1016/0378-4274(95)03375-U

9. Arab, M. M.; Yadollahi, A.; Hosseini-Mazinani, M.; Bagheri, S. J. Genet. Eng. Biotechnol. 2014, 12, 103-110., https://doi.org/10.1016/j.jgeb.2014.10.002

10. Mei, L.; Lu, Z.; Zhang, W.; Wu, Z.; Zhang, X.; Wang, Y.; Luo, Y.; Li, C.; Jia, Y. Biomaterials 2013, 34, 10328-10337., https://doi.org/10.1016/j.biomaterials.2013.09.045

11. Kikuchi, Y.; Sunada, K.; Iyoda, T.; Hashimoto, K.; Fujishima, A. J. Photochem. Photobiol. 1997, 106, 51-56. https://doi.org/10.1016/S1010-6030(97)00038-5

12. Huling, S.; Pivetz, B. 2006, USEPA Engineering Issue, PA/600/R-06/72, 5863

13. Veres, Á.; Rica, T.; Janovák, L.; Dömök, M.; Buzás, N.; Zöllmer, V.; Seemann, T.; Richardt, A.; Dékány, I. Catal. Today 2012, 181, 156-162., https://doi.org/10.1016/j.cattod.2011.05.028

14. Tallósy, S. P. Ph.D. Dissertation, University of Szeged, 2016

15. ISO 27447 Fine ceramics (advanced ceramics, advanced technical ceramics) - Test method for antibacterial activity of semiconducting photocatalytic materials. 2009

16. Veres, Á.; Ménesi, J.; Juhász, Á., Berkesi, O.; Ábrahám, N.; Bohus, G.; Oszkó, A.; Pótári, G.; Buzás, N.; Janovák, L.; Dékány, I. Colloid Polym. Sci. 2013, 292, 207-217., https://doi.org/10.1007/s00396-013-3063-1

\section{Köszönetnyilvánítás}

A cikkben bemutatott eredmények részben a GINOP-2.3.2-15-2016-00013 azonosító számú pályázati forrásokból kerültek finanszírozásra. Janovák László köszöni a Magyar Tudományos Akadémia Bolyai János Kutatási Ösztöndíj Kuratóriumának támogatását, ill. Mérai László az Emberi Erőforrások Minisztériumának UNKP-17-2-I-SZTE-36 sorszámú pályázatának támogatását.

A kutatást az Emberi Erőforrások Minisztériuma támogatta 20391-3/2018/FEKUSTRAT.

17. Tallósy, S. P.; Janovák, L.; Nagy, E.; Deák, Á.; Juhász, Á.; Csapó, E.; Buzás, N.; Dékány, I. Appl. Surf. Sci. 2016, 371, 139-150., https://doi.org/10.1016/j.apsusc.2016.02.202

18. Janovák, L.; Deák, Á.;Tallósy, S. P.; Sebők, D.;Csapó, E.;Bohinc, K.;Abram, A.;Pálinkó I.; Dékány, I. Surf. Coat. Technol. 2017, 326, 316-326., https://doi.org/10.1016/j.surfcoat.2017.07.072

19. Tallósy, S. P.; Janovák, L.; Ménesi, J.; Nagy, E.; Juhász, Á.; Dékány, I. J. Adv. Oxid. Technol. 2014, 17, 9-16., ISSN: 12038407

20. Tallósy, S. P.; Janovák, L.; Ménesi, J.; Nagy, E.; Juhász, Á.; Dékány, I.; Balázs, L.; Deme, I.; Buzás, N.; Dékány, I. Environ. Sci. Poll. R. 2014, 21, 1155-1167., https://doi.org/10.1007/s11356-014-2568-6

21. ISO 22196 Measurement of antibacterial activity on plastics and other non-porous surfaces 2011

22. Barthlott, W.; Ehler, N., Trop. Subtrop. Pflanzenwelt 1977, 19, 105.

23. Ming, W.; Wu, D.; van Benthem, R.; de With, G. Nano Lett. 2005, 5, 2298-2301., https://doi.org/10.1021/n10517363

24. Ta, V. D.; Dunn, A.; Wasley, T. J.; Li, J.; Kay, R. W.; Stringer, J.; Smith, P. J.; Esenturk, E.; Connaughtond, C.; Shephard, J. D. Appl. Surf. Sci. 2016, 365, 153-159., https://doi.org/10.1016/j.apsusc.2016.03.054

25. Feng, L.; Li, S.;Li, Y.; Li, H.;Zhang, L.;Zhai, J; Song, Y.; Liu, B.;Jiang, L.; Zhu, D. Adv. Mater. 2002, 14, 1857-1860. https://doi.org/10.1002/adma.200290020

26. Deák, Á.; Janovák, L.; Csapó, E.; Ungor, D.; Pálinkó, I.; Puskás, S.; Ördög, T.; Ricza, T.; Dékány, I. Appl. Surf. Sci. 2016, 389, 294-302., https://doi.org/10.1016/j.apsusc.2016.07.127

27. Deák, Á; Janovák, L; Tallósy, S. P.; Bitó, T.; Sebok, D.; Buzás, N.; Palinko, I.; Dékány, I. Langmuir 2015, 31, 2019-2027., https://doi.org/10.1021/la504096t

28. Janovák, L.; Dernovics, Á.; Mérai, L.; Deák, Á.; Sebők, D.; Csapó, E.; Varga, A.; Dékány, I.; Janáky, C.Chem. Commun. 2018, 54, 650-653., https://doi.org/10.1039/C7CC07671A

29. Ghosh, S.; Kouamé, N. A.; Ramos, L.; Remita, S.; Dazzi, A.; Deniset-Besseau, A.; Beaunier, P.; Goubard, F.; Aubert, P. H.; Remita, H. Nat. Mater. 2015, 14, 505-511., https://doi.org/10.1038/nmat4220

30. Floresyona, D.; Goubard, F.; Aubert, P. H.; Lampre, I.; Mathurin, J.; Dazzi, A.; Ghosh, S.; Beaunier, P.; Brisset, F.; Remita, S.; Ramos, L.; Remita, H. Appl. Catal. B-Environ. 2017, 209, 23-32., https://doi.org/10.1016/j.apcatb.2017.02.069

31. Zisman, W. A. Adv. Chem. Ser. 1964, 43, 1-8. https://doi.org/10.1021/ba-1964-0043.ch001 
Photoreactive hybrid layers with dual self-cleaning and photocatalytic properties for elimination of surface bacteria

Interdisciplinary researches of nanotechnology and microbiology have become great interest to develop environmental applications against bacteria causing nosocomial infections ${ }^{1-5}$. Nosocomial infections caused by multidrug-resistant microorganisms, such as methicillin-resistant Staphylococcus aureus (MRSA) ${ }^{4}$, Acinetobacter baumannii, and Pseudomonas aeruginosa can be observed frequently in hospital settings. These microorganism are common pathogenic bacteria with a possible multidrug resistance by mutation ${ }^{6,7}$ and they cause serious public health problems. The most serious concern with these types of bacteria is that some of them have become resistant to almost all antibiotics available at the present time and are able to cause serious disease. Methicillin resistant Staphylococcus aureus and multidrug resistant Pseudomonas aeruginosa can cause nosocomial infections and are responsible for postoperative infection. Interdisciplinary researches of nanotechnology and microbiology have become great interest to develop environmental applications against bacteria causing nosocomial infections ${ }^{8}$. Antimicrobial applications are able to inactivate bacteria, viruses and fungi on different surfaces, in water or in the air, so they can be the main actor of prevention in the health care facilities ${ }^{8}$. There are various techniques to develop antimicrobial surfaces, but only a few optimize the structure and the chemical properties ${ }^{6-8}$. These developed self- sterilizing surfaces can solve this problem, because they can inactivate a wide spectrum of microorganisms. The increasing application of nanoparticles as antimicrobials has been reviewed in industries, medicine, cosmetics, textiles, and food packaging ${ }^{5-8}$.

The first class of self-cleaning surfaces is the photocatalytic coatings, which can decompose organic materials chemically upon light exposure ${ }^{9}, 10$. Photocatalysis is a photo-induced reaction, in which the photons excite the photocatalyst particles and the irradiated photocatalyst particles produce highly reactive oxygen species [such as superoxide radical ion $\left(\mathrm{O}_{2} \cdot^{-}\right)$hydrogen peroxide $\left(\mathrm{H}_{2} \mathrm{O}_{2}\right)$, or hydroxyl radical $\left({ }^{\circ} \mathrm{HO}\right)$, with high oxidation potential values ${ }^{11,12}$. Various semiconductor particles (e.g. $\mathrm{TiO}_{2}$ or $\mathrm{ZnO}$ ) irradiated with light of appropriate excitation wavelength show photocatalytic activity. For the purpose of practical applications, the attachment of catalyst particles onto support materials, such as glass, textile, paper, or ceramic tiles, is essential. Polymers are often used as photocatalyst matrices due to their flexibility, low weight, impact resistance, and low cost (Fig. 1.). The photocatalyst particles embedded into the polymer matrix can also preserve their photocatalytic activity beside the achieved adequate mechanical properties (Fig. 2.) ${ }^{13-17}$. However, in the case of polymer based photoreactive composite layer, the undesired photooxidation of the polymer matrix has to be avoided. In order to prevent the polymer photodegradation, hydroxyapatite (HAp) lamellae containing $\mathrm{TiO}_{2} /$ polyacrylate photoreactive thin films were prepared, where the HAp microlamellae serve as inert spacer in the
$\mathrm{TiO}_{2} /$ polymer hybrid material and prevent the direct contact of $\mathrm{TiO}_{2}$ with organic polymer binder ${ }^{18}$. So the gravimetrically measured weight loss (i.e. the photooxidation of polymer) was $75 \%$ lower in the case of Hap containing composite film (Fig. 3.) Moreover, it was also presented that the obtained hybrid layer shows improved photocatalytic and antibacterial properties because the biocompatible and HAp microlamellae are potential candidates as support materials for the attached P25 TiO photocatalyst $\mathrm{NPs}^{18}$. Functional surfaces with photocatalyst content can kill numerous microorganisms because of its photocatalytic properties and the strong photocatalytic activity of this hybrid thin films are reported in the literature $17,19,20,21$. Due to the appearance of reactive radicals, the photocatalyst particles can degrade many organic compounds and inactivate microorganisms via destroying the cell wall and their DNA, respectively. This destruction mechanism is due to breaking covalent bonds in peptidoglycan layer, which is mainly responsible for the stability of the cell wall in Gram-positive $(\mathrm{GR}+)$ and Gram-negative (GR-) bacteria (Fig. 4. ${ }^{20}$. The developed nanohybrid films have antibacterial properties even against Enterococcus faecalis (Fig. 5.), Escherichia coli, or antibiotic resistant Staphylococcus aureus bacteria ${ }^{17,19,20 .}$

The second class of self-cleaning surfaces is the superhydrophobic coatings. In recent years, superhydrophobic surfaces with water contact angle $(\Theta)$ higher than $150^{\circ}$ have received considerable attention due to their significant potential for practical applications. The well-known Lotus effect involves superhydrophobicity and self-cleaning properties. This property is the result of dual surface roughness in micro- and nanometer scales superimposed on a hydrophobic surface functionality, similar to the microscopic structure of lotus leaf surfaces (Fig. 6. $)^{22}$. It is also well-known that much effort has been devoted to develop artificial superhydrophobic surfaces by mimicking the lotus leaf structure ${ }^{23-26}$. In general, in creating a potentially superhydrophobic surface, the low energy as well as the adequate roughness of the surface are crucial factors. The increase in the surface roughness of a slightly hydrophobic solid surface $\left(\theta>90^{\circ}\right)$ results in the significant increase in the contact angle $\left(\theta>150^{\circ}\right)$ (Fig. 7.). Surfaces that display contact angles greater than $150^{\circ}$ for low surface tension liquids such as oils and alcohols are known as superoleophobic surfaces (Fig. 8.).

The advantageous properties of the low energy water repellent and the high energy photoreactive composite thin films can also be combine. In 2015 we have successfully synthesized photocatalytic layered double oxide (LDO) particles with structural rough surface on the micro- and nanoscale (Fig. 9. $)^{27}$. Moreover, due to the $\sim 12 \mathrm{wt} \% \mathrm{ZnO}$ content, the calcined LDO particles displayed photocatalytic properties on UV-A light irradiation (Fig 10.). Furthermore, the surface energy of the rough surface LDO photocatalyst particles was lowered by using a low-energy fluoropolymer 
binder material. As the result, the prepared hybrid rough surfaces displayed photocatalytic as well as superhydrophobic dual properties with antibacterial behaviors (Fig 11.) ${ }^{26}$. The state-of-the-art bifunctional materials possessing superhydrophobic and photoreactive properties are semiconductor photocatalyst/organic polymer nanocomposites, however, these nanocomposite configurations bear considerable drawbacks. Recently, the photocatalytic activity of different conducting polymers [for example poly(diphenylbutadiyne) (PDPB), poly (3,4-ethylenedioxythiophene) (PEDOT), and P3HT was demonstrated under visible light irradiation without the assistance of sacrificial reagents or precious metal cocatalysts 29, 30. In 2018 we demonstrated the facile preparation of a monolithic, microstructured organic conjugated polymer (P3HT) film, with adjustable surface roughness and visible light photoactivity ${ }^{28}$. Zisman analysis ${ }^{31}$ was performed with a set of different liquids with increasing surface tension to quantify the non-wettability of the low-energy superhydrophobic P3HT surfaces. Fig. 12A presents the determined cosine value of contact angles as a function of liquid surface tensions. The dashed lines represent the best fits for the measured points and are extrapolated to intersect with the value of $\cos \Theta_{\mathrm{w}}=1(\Theta=$ $\sim 0^{\circ}$ ). Most importantly, the increase of the surface roughness of the P3HT caused a massive decrease in the measured surface energy value $\left(16.4 \mathrm{~mJ} \mathrm{~m}^{-2}\right)$. Beside the waterrepellent superhydrophobic nature of the roughneded polymer film, the photoactivity of the conducting polymer was also presented (Fig. 12B). Under simulated solar irradiation the P3HT films showed obvious photocatalytic activity. 